Original Research

\title{
Family Support on the Activities of Elderly Hypertension Patients in Elderly Gymnastics Activities
}

\section{Wachidah Yuniartika and Fauzan Muhammad}

Faculty of Health Science, Universitas Muhammadiyah Surakarta, Indonesia

\begin{abstract}
Introduction: The aging process results in decreased body resistance, physiological functions and diseases which attack the elderly, such as hypertension. Elderly gymnastics is a mild exercise that is applied to the elderly. High family support will make the elderly more actively participate in elderly gymnastics activities, and vice versa. The aim of study was to determine the relationship of Family Support to the Activity of Elderly in Pajang Village.
\end{abstract}

Methods: The design of the study was quantitative research with a cross sectional approach. The population of the study was all elderly people with hypertension who were aged 60 years and over who participated in elderly gymnastics, with total sampling at 95 respondents. This was then analyzed using the Kendall's Tau formula.

Results: The majority of family support was enough (38.8\%) and the active category $(63.2 \%)$, with bivariate analysis a value of $0.001(<0.05)$, with a magnitude of 0.082 .

Conclusion: Families can help overcome the problems of the elderly and provide support for exercise activities. Families can also increase selfconfidence to improve the health of the elderly. There is a significant relationship of family support for the activeness of elderly hypertension patients in elderly gymnastics activities in Pajang Village.

\section{ARTICLE HISTORY}

Received: Dec 26, 2019

Accepted: Dec 31, 2019

\section{KEYWORDS}

aging; elderly; hypertension; family support; gymnastics activities

\section{CONTACT}

Wachidah Yuniartika

$\triangle$ wachidah.yuniartika@ums.ac.id

$\equiv$ Faculty of Health Science,

Universitas Muhammadiyah

Surakarta, Indonesia

Cite this as: Yuniartika, W. \& Muhammad, F. (2019). Family Support on the Activities of Elderly Hypertension Patients in Elderly Gymnastics Activities. Jurnal Ners,14(3si),354-357.doi:http://dx.doi.org/10.20473/jn.v14i3(si).17213

\section{INTRODUCTION}

Increasing human life expectancy is one manifestation of the success of Indonesia's development. Projected data for the average life expectancy of Indonesian citizens in 2015-2020 has increased to 71.7 years, while the data is projected in 2010-2015, which is 70.7 years (Hasugian, Lubis, \& Tukiman, 2012). Data from the Indonesian Ministry of Health in 2017, estimates that in 2017 there are 23.66 million elderly people in Indonesia. The Central Java Province entered the second rank and in Surakarta alone there were 55 thousand elderly people. Data from the 2013 Riskesdas (Health IM, 2013), the health problems that arise in the highest elderly are hypertension. Then according to RI Law Number 36 of 2009 concerning health, one of the goals of the health program for the elderly is to stay healthy, so that the government guarantees the availability of health service facilities by establishing elderly posyandu in each region. The elderly posyandu activities include elderly gymnastics (Sunaryo, Wijayanti R, 2016).

Elderly gymnastics is a mild exercise that is applied to the elderly with movements that are easy to do and which are not burdensome (Widianti, 2018). This exercise will help the elderly to stay fit and fresh, exercise strong bones, encourage the heart to work optimally, eliminate free radicals in the body, inhibit the aging process, and increase immunity in the body. There are several factors that influence elderly visits, but the most influential is family support. Family support for the elderly provides peace of mind and pleasure to the elderly as well as this facilitates the elderly to participate in elderly gymnastics activities. High family support will make the elderly more actively participate in elderly gymnastics activities, and vice versa (Purnawati, 2014; Susilowati, 2014). 
The role of the family has a big influence on the psychology of the elderly because it can provide peace of mind and happy feelings to the elderly and provides a safe sense of security in the elderly. Elderly people will feel very cared for if there is a lot of support from the family.

Preliminary studies conducted in Pajang Village include 6 out of 10 elderly who are not actively participating in elderly gymnastics by reason of lack of family support, families do not deliver the elderly to take part in elderly exercises, do not remind elderly gymnastics activities, and families forbid elderly people from taking elderly exercise because of the elderly Hypertension sufferers.

The purpose of this study was to determine the relationship of family support to the activeness of elderly people with hypertension in elderly gymnastics activities.

\section{MATERIALS AND METHODS}

This researcher is a type of quantitative research using a cross sectional approach. The population of the study were all elderly Hypertension patients aged 60 years and over who participated in elderly gymnastics, at 95 respondents. Sampling using Total Sampling, This research was conducted at Pajang Village on 8 October-8 November 2018. An instrument of the independent variable family support with a guide to the review of Friedman theory at 12 questions with the Likert scale and the dependent variable on the activity of the elderly using a documentation sheet that records the presence of the elderly in 1 year. The course of the research was by distributing questionnaires directly to the elderly who attended the elderly gymnastics and home visits when the elderly with hypertension were not present at public health. Univariate analysis using a frequency distribution and analysis bivariate Kendall's tau formula.

\section{RESULTS}

The results of the study from table 1 are known that based on the characteristics of respondents family support shows that the majority of respondents received sufficient family support, namely 37 people $(38.8 \%)$ and the active elderly people with the most hypertension, namely active with a number of 60 respondents $(63.2 \%)$.

The results of the analysis show that the significant value is 0.001 which is $<0.05$, then $\mathrm{HO}$ is rejected. This means that there is a significant relationship with the magnitude of the relationship of 0.082 , so that there is a relationship between family support and the activity of the elderly people with hypertension who are very strong.

\section{DISCUSSION}

The results showed that the majority of the elderly who participated in elderly gymnastics activities received adequate family support, namely 37 people (38.8\%) and included an active category with 60 people (63.2\%). Family support plays an active role in encouraging the willingness of the elderly to take part in elderly exercise (Panjaitan A., Frelestanty E, 2017). Family support given to the elderly is an important element to help in solving problems, especially in the context of health. The existence of family support will make the elderly feel more confident and have the motivation to deal with and maintain their health problems (Padila, 2016). The family can also be a strong influence for the elderly in assisting the elderly, reminding the elderly and helping them to overcome various problems in participating in elderly gymnastics activities (Hamalding $H, 2017$ ).

The elderly can get information about the benefits of elderly gymnastics from their daily lives and based on personal experience. Elderly people who attend the posyandu activities will certainly get health information about how to maintain a healthy lifestyle with all the problems or limitations they have, so that

Table 1. Distribution of characteristics based on family support and activeness of the elderly

\begin{tabular}{llccc}
\hline No & Variable & & Frequency & Percentage (\%) \\
\hline $\mathbf{1}$ & Family support & Good & 22 & $23,2 \%$ \\
& & Enough & 37 & $38,8 \%$ \\
& & Less & 36 & $37,9 \%$ \\
\hline $\mathbf{2}$ & Activeness of the elderly & Active & 60 & $63,2 \%$ \\
& & Not Active & 35 & $36,8 \%$ \\
\hline & Total & 95 & $100 \%$ \\
\hline
\end{tabular}

Table 2.Analysis result

\begin{tabular}{|c|c|c|c|c|}
\hline & & & Activeness of the elderly & Family support \\
\hline \multirow[t]{6}{*}{ Kendall's Tau } & Activeness of the elderly & $\begin{array}{l}\text { Correlation } \\
\text { Coefficient }\end{array}$ & 1.000 & 0.802 \\
\hline & & Sig. (2-tailed) & & 0.000 \\
\hline & & $\mathrm{N}$ & 95 & 95 \\
\hline & Family support & $\begin{array}{l}\text { Correlation } \\
\text { Coefficient }\end{array}$ & 0.802 & 1.000 \\
\hline & & Sig. (2-tailed) & 0.000 & \\
\hline & & $\mathrm{N}$ & 95 & 95 \\
\hline
\end{tabular}


based on experience and knowledge will make the interest of the elderly towards the activities carried out at the posyandu high, one of which is elderly gymnastics (Novianti, 2018). Being active is defined if its presence is more than $75 \%$, or attendance is more than 9 times in one year (Arikunto, 2010).

The results of the bivariate analysis show that the significant value is 0.001 which is $<0.05$, then $\mathrm{HO}$ is rejected. It means that there is a relationship between family support and the activity of elderly Hypertension sufferers in participating in elderly gymnastics activities in Pajang Village. The size of the relationship is 0.082 , which means the relationship of family support with the activity of elderly people with hypertension is very strong

Family support has an important role in encouraging the elderly to participate in elderly gymnastics activities (Noviana, 2013). As well as the role of the family also has a big influence in the psychology of the elderly because it can provide peace of mind and feelings of pleasure in the elderly and provide a safe sense of security in the elderly. Elderly people will feel very cared for if there is a lot of support from the family. So that the family has an important role in the lives of the elderly. This is supported by the opinion who said that support from the family can also increase self-confidence in the elderly, so that the elderly will tend to positive things, for example participating in elderly gymnastics activities to improve the health of the elderly (Center IM of HD\&I, 2016). In addition, families play an important role in strengthening self-management (Peñarrieta et al., 2015).

The family has support functions in the form of information support, assessment support, instrumental support, and emotional support, as well as family support provided for families with diverse elderly. The family has information support that functions as an advocate, advice and guidance and provides information. Family assessment support allows families to be supportive, useful, and caring. And the emotional support of functioning families as a safe and comfortable place to rest, and instrumental support put the family as a source of practical and concrete assistance. Because basically the elderly need security and love from the family (Flynn et al., 2013; Novita \& Novitasari, 2017).

In addition, family support can be described by giving attention to the elderly in reminding the elderly gymnastics activity schedule, bringing the elderly to follow elderly gymnastics, listening to the complaints of the elderly and giving awards to the elderly and motivation or encouragement of life for the elderly.

\section{CONCLUSION}

The conclusion from the results of the study that there is a very strong and significant relationship between family support for the activeness of elderly people with hypertension in elderly gymnastics activities in Pajang Village.

\section{REFERENCES}

Arikunto, S. (2010). Research Procedure A Practice Approach. Jakarta: Rineka Cipta.

Center IM of HD\&I. (2016). Elderly Situation in Indonesia. $\quad$ Retrieved from http://www.depkes.go.id/

Flynn, S. J., Ameling, J. M., Hill-Briggs, F., Wolff, J. L., Bone, L. R., Levine, D. M., ... Boulware, L. E. (2013). Facilitators and barriers to hypertension self-management in urban African Americans: Perspectives of patients and family members. Patient Preference and Adherence. https://doi.org/10.2147/PPA.S46517

Hamalding H, M. (2017). Relationship between Family Support and Quality of Life (Qol) in Stroke Events. Jurnal Kesehatan Masyarakat, 7(2), 146-152. Retrieved from https://media.neliti.com/

Hasugian, F. H., Lubis, N. L., \& Tukiman. (2012). Hubungan Perilaku Lansia dan Dukungan Keluarga Terhadap Pemanfaatan Posyandu Lansia di Wilayah Kerja Puskesmas Darussalam Tahun 2012. Kebijakan, Promosi Kesehatan Dan Biostatistik.

Health IM. (2013). Indonesian Health Profile. Retrieved from http://www.depkes.go.id/

Noviana. (2013). Factors Associated with Elderly Visits to Elderly in Public Health. Jurnal Keperawatan STIKES Ngudi Waluyo Ung.

Novianti, D. (2018). Factors Affecting Elderly Behavior in Following Elderly Gymnastics in the Public Health Working Area. Jurnal Keperawatan Silampari, 1(9), 123-138.

Novita, D. A., \& Novitasari, R. (2017). Hubungan Antara Dukungan Sosial dan Kualitas Hidup pada Remaja Berkebutuhan Khusus. PSIKODIMENSIA.

https://doi.org/10.24167/psiko.v16i1.937

Padila. (2016). Family Nursing. Yogyakarta: Nuhamedika.

Panjaitan A., Frelestanty E, L. S. (2017). Family Support for Active Activities of Elderly People in Joining Elderly Public Health at Emparu Health Center. Jurnal Kesehatan STIKes Kapuas Raya Sintang, 3(2), 78-81. Retrieved from http://ejournal.poltekkes-pontianak.ac.id/

Peñarrieta, M. I., Flores-Barrios, F., Gutiérrez-Gómez, T., Piñones-Martínez, S., Resendiz-Gonzalez, E., \& Quintero-Valle, L. maría. (2015). Selfmanagement and family support in chronic diseases. Journal of Nursing Education and 
Practice.

https://doi.org/10.5430/jnep.v5n11p73

Purnawati, N. (2014). Faktor Faktor yang Mempengaruhi Kunjungan Lansia dalam Kegiatan Posyandu di Desa Plumbon Kec. Mojolaban Sukoharjo. Muhammadiyah Surakarta.

Sunaryo, Wijayanti R, K. M. (2016). Gerontik Nursing Care. Yogyakarta: CV.Andi OFFSET.
Susilowati. (2014). Faktor Faktor yang Mempengaruhi Kunjungan Lanjut Usia ke Posyandu Lanjut Usia Desa Tegalgiri Nogosari Boyolali. Muhammadiyah Surakarta.

Widianti, T. A. (2018). Health Gymnastics. Yogyakarta: Nuha Medika. 